\title{
Influence of different approaches and forms of fertilizer application on growth, yield, yield response and response yard stick of hybrid maize in eastern dry zone of Karnataka
}

\author{
Chandrakant* and P.K. Basavaraja \\ Department of Soil Science and Agricultural Chemistry, College of Agriculture, University of Agricultural \\ Sciences, GKVK, BENGALURU (KARNATAKA) INDIA(Email : chandrunawadgi@gmail.com)
}

\begin{abstract}
A field experiment was conducted at Zonal Agricultural Research Station, University of Agricultural Sciences, GKVK, Bangalore to study the influence of soil and foliar application of different forms of fertilizers through different approaches on growth, yield,yield response and response yard stick of hybrid maize in eastern dry zone of Karnataka. The experiment was laid out in RCBD with ten treatments and replicated thrice. The results revealed that 100 per cent soil test crop response (STCR) dose through soluble fertilizer with 3 splits and 3 sprays of 1 per cent 19 all recorded higher growth parameter like plant height (246.07 $\mathrm{cm}$ ), number of rows per cob (18.20), number of grains per row (44.38), number of sheaths per cob (16.00) and yield parameters like grain yield $\left(98.22 \mathrm{q} \mathrm{ha}^{-1}\right)$ and stover yield $\left(130.96 \mathrm{q} \mathrm{ha}^{-1}\right)$. Similarly, higher crude protein yield $\left(1100.79 \mathrm{~kg} \mathrm{ha}^{-1}\right)$ and yield response $\left(1566.67 \mathrm{~kg} \mathrm{ha}^{-1}\right)$ were recorded in the same treatment whereas higher response yard stick $\left(10.12 \mathrm{~kg} \mathrm{ha}^{-1}\right)$ was recorded in the treatment which received 50 per cent STCR dose through soluble fertilizer with 3 splits and 3 sprays followed by 100 per cent STCR dose through soluble fertilizer with 3 splits and 3 sprays of 1 per cent 19 all. Higher response recorded in this treatment may be due to effective utilization of NPK nutrients by the crop through soluble fertilizers due to its easy solubility and better uptake of nutrients under STCR approach.
\end{abstract}

Key Words : STCR, Soluble fertilizer, Conventional fertilizer, Response yard stick

View Point Article : Chandrakant and Basavaraja, K. (2018). Influence of different approaches and forms of fertilizer application on growth, yield, yield response and response yard stick of hybrid maize in eastern dry zone of Karnataka. Internat. J. agric. Sci., 14 (1) : 180185, DOI:10.15740/HAS/IJAS/14.1/180-185.

Article History : Received : 23.10.2017; Revised : 28.11.2017; Accepted : 11.12.2017

* Author for correspondence: 